\title{
The Moderating Impact of Team Tenure on Team Trust - Team Performance Relationship with Relevance to Executive Level Employees of Sri Lankan Tyre Manufacturing Industry
}

\author{
Rajapaksha B.P. ${ }^{1}$, Nishanthi H.M. ${ }^{2}$ \\ ${ }^{1,2}$ Department of Human Resource Management, University of Kelaniya, Sri Lanka. \\ ${ }^{1}$ bagyaraja561@gmail.com, ${ }^{2}$ menaka@kln.ac.lk
}

\begin{abstract}
Even though, many determinants of team performance are found in extended literature, team trust and the moderating effect of team tenure is little investigated in Sri Lankan context, and it has not been studied yet. Bridging the gap in this context, the current study assessed the moderating impact of team tenure on team trust and team performance relationship in Sri Lankan tyre manufacturing industry. The current study was conducted as a cross-sectional study among a sample of one hundred and ninety-two executive level employees selected from four major tyre manufacturing organizations following the stratified random sampling technique. Primary data were collected using a standard questionnaire distributed via Google form. The collected data were analysed with the support the SPSS employing correlation, regression, descriptive statistics and process matrix. It is found that team tenure does not moderate the relationship between team trust and team performance, and also founded that strong positive relationship between team trust and team performance. Moreover, team trust impact positively on team performance and team tenure does not impact team trust and team performance separately. It is recommended to tyre manufacturing organizations to facilitate more open communication and information sharing in order to improve executive level employees trust within teams, which in turn, will affect their team performance. Future researchers can use other variables like organizational support, team diversity, and personality as moderators of their study.
\end{abstract}

Keywords: Team Trust, Team Performance, Team Tenure, Executive level employees, Tyre manufacturing industry

Copyright: (C) 2021 Rajapaksha B.P. and Nishanthi H.M. This is an open access article distributed under the Creative Commons Attribution License, which permits unrestricted use, distribution, and reproduction in any medium, provided the original work is properly cited.

Correspondence: menaka@kln.ac.lk

ORCID of authors: Nishanthi H.M. - (iD https://orcid.org/0000-0001-8519-1501

DOI: http://doi.org/10.4038/kjm.v10i2.7695 


\section{Introduction}

Firms are progressively relying on teams and the motivation to find ways to optimize team performance has been increased lately (Kisamore \& Morissette, 2020). What an organization expects from a team is performance. Therefore, whether an organization is successful or not can be indicated by team performance. When bridging the relationship between individual performance and organizational performance, teams play a pivotal role (Edmondson, 2002). When improving organizational performance, collaborative team activities are considered a critical component, even though individual employee is the basic asset for performance (Edmondson, 2002).

Kozloweski and Ilgen, (2006) defined teams as two or more people who interact socially and share a goal, perform tasks relevant to their organization, have some task interdependence but different roles, and work together in an organization. As opposed to (McGrath, 1984) traditional input process output team functioning model recent research focused on team emergent states such as attitudes, values and beliefs (Carter et al, 2018; Shuffer et al, 2018). These emergent states are occurred due to team interactions and they vary according to context (Marks, Mathieu \& Zaccaro, 2001). Team trust should be considered as one of the emergent states that scholars and practitioners take into account. Fulmer and Gelfand, (2012, p.1174) conceptualized team trust as "a shared psychological state among team members comprising willingness to accept vulnerability based on positive expectations of a specific other or others"

Even though many studies that examined the team trust and team performance relationship, see: Kisamore \& Morissette, (2020); Eden, Ozen \& Atsan, (2003) and Mach Piera \& Baruch, (2015) the results of those empirical researches range from very weak to strong. (Kisamore \& Morissette, 2020) These variations are results from team design and methodological factors. (Breuer, Hüffmeier and Hertel, 2016; De Jong, Dirks and Gillespie, 2016)

Social exchange theory (Blau, 1964) explained that shared experience and its growth over time evolve trust. (Kisamore \& Morissette, 2020) suggested that team trust performance relationship differences should be examined as a function of team tenure. It is to determine when teams evolve over time, whether there is a trajectory relationship. Schippers et al, (2003) explain team tenure as the length of time that team member has been with the team.

Kozlowski et al, (1999) identified that there is a positive impact on performance by team tenure. However, there is little literature on the moderating effect of team tenure on team trust and team performance relationship. Therefore, we can emphasize that there is a literature gap in team tenures moderating effect. (Kisamore \& Morissette, 2020)

Furthermore, this study is based on the fact that tyre manufacturing companies do have trust within teams, which is aiming to improve team performance. The current study aims to advance understanding of the team trust - team performance relationship in business teams and further expand knowledge about the new moderator of the relationship.

This study did not carry out in Sri Lankan tyre manufacturing firms and therefore we can emphasize that there is a contextual gap in these variables. Sri Lankan tyre manufacturing organizations are not so different from others in worldwide in terms of striving for performance to be globally competitive. Sri Lankan tyre manufacturers produce a range of tyres that suits many types of vehicles including bicycles, cars, motorcycles, buses, trucks, and heavy equipment except for aircraft tyres. A considerable portion of Sri Lankan tyre manufacturers serves the local market and the country also exports pneumatic tyres to the USA, Canada, Germany and Mexico. When 
considering export earnings both pneumatic tyres and solid tyres were the major contributors, which is $38 \%$ and $61 \%$ respectively in 2012 (Sri Lanka Export Development Board, 2021). This study examines whether team tenure moderates the trust performance relationship in tyre manufacturing business teams. It is expected that the strength of the relationship will vary based on team tenure. Executive level employees are included in this study and they perform activities in management functions.

Trust is important for achieving a common goal and holding the team together. (Lin et al, 2008) Peters and Manz, (2007) mentioned that teams with low levels of trust among their members were less likely to share information and ideas which led to lower performance. However, Sri Lankan firms did not go through this kind of investigation. Besides, how team tenure impacts the team trust and performance relationship is unclear. Performance is a critical factor for success in tyre manufacturing organizations as it is for other organizations. A team is an entity that brings success to an organization, its performance is vital. Therefore, team performance drawbacks should be examined. One of the leading tyre manufacturer in Sri Lanka, which is X International Tyres (Pvt) Ltd. annual report 19/20 provide performance statistics that reflect performance drawbacks. See Appendix A.

The above figures show that statistics were decreasing in the last two years. Therefore, there is a performance issue in this organization and researcher include several other major tyre manufacturers to study the industry for the performance gap. As suggested by Kisamore and Morissette, (2020) the underline problem of this study is elevated to investigate the moderating effect of team tenure on team trust-performance relationship in the Sri Lankan tyre manufacturing industry. Therefore, the research problem should be as follows,

"Does team tenure moderate the relationship between team trust - team performance in Sri Lankan tyre manufacturing industry?"

\section{Literature Review}

\section{Team Trust}

Trust as a concept received considerable attention over the past few decades in organizational and applied psychology. Trust is expressed in individual, teams and organization levels and considered as an interpersonal and collective phenomenon (Kramer, 1999; Puusa \&Tolvanen, 2006). Organizations have moved towards flatter and more team-based structures because of trust in the workgroup or team have become interesting in studying (Mathieu, Marks \& Zaccaro, 2001). In research agenda trust is raised because of the increased importance of interpersonal and group dynamics in attaining effective collaboration firms are increasingly looking for ways to invest in conditions that facilitate trust among members to enhance their positive team working conditions (Kozlowski \& Bell, 2003).

Studies show that an increase in trust results in more positive workplace behaviours and attitudes such has more open communication and information sharing. Team trust has been associated with improvements in communication, teamwork (Costa, Roe \& Taillieu, 2001). Researchers like Lewis \& Weigert, (1985); Mayer, Davis \& Schoorman, (1995) agree that trust as a highly complex, multidimensional and abstract phenomenon including distinct but related components. Individual and relational components are the most seen definitions and models in trust, respectively regarding the trustor and his or her relationship with the trustee(s) (Mayer et al., 1995; Smith \& Barclay, 1997).Furthermore trust evolved by shared experiences and time taken to gain experiences, which is explained by social exchange theory (Blau, 1964).

Trust shows the process of one party (the trustor) trusting another party (the trustee) 
(Costa \& Anderson, 2011). Trust is defined as "a willingness of a party to be vulnerable to the actions of another party based on the expectation that the other will perform a particular action important to the trustor, irrespective of the ability to monitor or control that party" (Mayer et al., 1995, p.712). In this definition, the trustor and his or her relationship with the trustee(s) include both an individual and relational component of trust. The trustor's propensity to trust others showed in individual component and perceived trustworthiness is the relational component. This shows one party bestow on trust to another party (Mayer et al., 1995). One of the behavioural consequence of trust is "willingness to become vulnerable". This is because of trustors own set of beliefs regarding the trustee is influence trustor to take actions (Lewis \& Weigert, 1985).

Trust can be examined as a collective phenomenon on a team level. "Team members' judgement about others" which is trustworthiness can be assessed based on information provided by interactional histories (Kramer, 1999).

Behaviours of cooperation and monitoring between teams members stem from individuals own propensity to trust others and on the perceived trustworthiness of the other team member because of trust between team members can be conceptualized as a latent construct (Costa \& Anderson, 2011).

When establishing and maintaining trust within teams' reciprocity is considered to be an issue. In addition, a person realizes that he is taking a considerable risk by trusting which may lead others to reciprocate the trust and behave in a trustworthy manner (Das \& Teng, 1998).

Trusting behaviours include a critical aspect of trust since they are the basis for reciprocity between individuals (Nooteboom, 2002). Even though trust within teams can be derived from individuals' beliefs regarding their team, it is likely that through interdependent demands and ongoing interactions individuals will develop trust (West, 2001).

Costa \& Anderson, (2011) explain four indicators of team trust. Those four indicators are,

1) Propensity to trust

2) Perceived trustworthiness

3) Cooperative behaviours

4) Monitoring behaviours

\section{Propensity to trust}

The general willingness to trust others is usually considered as a dispositional trait in the propensity to trust. Rotter, (1967, p651) defined this general willingness to trust "as an expectancy held by an individual or group that the word, promise, verbal or written statement of another individual or group can be relied upon." The propensity to trust is viewed as a personality trait that prompts summed up assumptions regarding the trustworthiness of others and that is steady across circumstances by few authors (Dasgupta, 1988; Farris, Senner \& Butterfield, 1973). Situational factors and team members affect the propensity to trust and ought to be seen as a more situational specific trait, however, it should be viewed as a relatively stable disposition (Rotter, 1980; Sitkin and Pablo; 1992). The propensity to trust is different life experiences, personality types, cultural backgrounds, education and several other socioeconomic factors (Mayer et al.1995)

Perception of trustworthiness and actions towards other members are likely to affect and be affected by a propensity to trust in work teams ongoing relationships. The presence or absence of trust determines the efficiency, adjustment and even survival of any group (Rotter, 1980). Hence, the willingness of one or more individuals in a social unit trust others is considered as the propensity to trust in this perspective.

\section{Perceived trustworthiness}


Perceived trustworthiness can be defined as "the extent to which individuals expect others to be and behave according to their claims" (Costa \& Anderson, 2011).

What individuals expect does have an emotional and cognitive ground (McAllister, 1995). Furthermore, these expectations develop from others who are willing to become vulnerable by perceptions or information regarding competence, benevolence, integrity, motives and intentions (Lewis \& Weigert, 1985; McAllister, 1995). There are three dimensions of perceived trustworthiness, which is suggested by Cummings and Bromiley (1996).

1) Makes good intentional efforts to act in a way that both explicit and implicit commitment.

2) Being sincere in whatever negotiations preceded such commitments.

3) When there is an opportunity, does not take excessive advantage.

These dimensions show the perceived trustworthiness among team members.

\section{Cooperative Behaviours}

It is the number of positive actions that shows the readiness of being vulnerable to others whose actions one does not control (Zand, 1972) and involve "engaging in some form of cooperation" with them (Dasgupta \& Gambetta, 1988). The dependence on others (Clark \& Payne, 1997), acceptance of influence (Smith \& Barclay, 1997), Openness to communication (Lewicki \& Bunker, 1996; Smith \& Barclay, 1997), Sharing information (Clark \& Payne, 1997; Currall \& Judge, 1995) and behave in a spirit of cooperation (Smith \& Barclay, 1997) are the cooperative behaviours. These behaviours are extremely related to one another and they are proved through research. Either they may occur simultaneously or one leads to another.
Therefore, it is observed as complementary (Currall \& Judge, 1995, Gillespio \& Maan, 2004; Smith \& Barclay, 1997). The dependence on each other is considered to be the cooperate behaviours within teams and open communication, acceptance of influence from others and personal involvement in the teams are included in it.

\section{Monitoring Behaviours}

Whether there is a need to exert other members work through monitoring, checking and surveillance behaviours are considered as monitoring behaviours. Furthermore, lack of trust is the reason for monitoring behaviours. The monitoring behaviours do need if team member trusts his or her colleagues' ability to perform well, or to be honest or benevolent (Costa \& Anderson, 2011). Monitoring is often experienced as negative behaviour in manager-led and longtermed work teams (Langfred, 2004). McAllister,(1995) argued that these behaviours frequently leads members to direct their efforts towards protecting their personal interest rather than cooperating and directing resources toward attaining team goals. The more team trust the lesser the monitoring behaviours and vice versa (Inkpen, Currall, Beamish, \& Kiling, 1997; Leifer \& Mills, 1996).

\section{Team Performance}

Team performance is regarded as the most often important outcome for the practitioners and researchers. Salas et al, (2009) stated that individual task work and interpersonal teamwork are the combinations, which create team performance.

Continuous problem solving, the continual search for alternative solutions, continuous improvement of quality outputs, error and wastage rates and productivity improvements should be considered as basic criteria for evaluating team performance. (Kirkman \& Shapiro, 1997; Manz \& Neck, 1997). Trust produce a high level of cooperation, which leads to attaining above mentioned high level 
and continuous goals (Astan, Erdem \& Ozen, 2003).

Hence trust is considered as a "hygiene factor" for team performance and furthermore as a necessary underpinning but not sufficient itself. It is not guaranteed that trust will improve team performance simply because exists, nor it present in team relationships (Astan, Erdem \& Ozen, 2003).

Manz and Neck, (1997) argued that excess trust leads to lack of questioning of creative criticism. As a hygiene factor trust is not present, team members will not help others willingly, unable to express their ideas fully and sincerely (Sitkin \& Roth, 1993;Jones \& George, 1998). Ultimately, the performance will be less than desired because of the lack of required synergy (Astan, Erdem \& Ozen, 2003).

Communication is considered as a key component for team success, especially for project teams throughout their project process. Pinto (1990) defined communication as "the provision of an appropriate network and necessary data to all key actors in the project implementation." Project teams are engaging in a three-way pattern communication with clients and parent organization. It is important to keep the communication channels open to ensure the transfer and exchange relevant information between these major parties (Pinto, 1990).

The next key component to measure team performance is trouble shooting. Pinto (1990) explained trouble shooting as the ability to handle unexpected crises and deviations from plan." Some planned tasks are going smoothly without problems occurring along the way (Pinto, 1990). Furthermore, project teams' projects should have constant finetuning and readjustment throughout their process in order to address these trouble spots. So final team performance factor is the availability of contingency plans, system or procedures that are in place in order to face unexpected crises and deviations from the plans (Pinto, 1990).

\section{Team Tenure}

Schippers et al, (2003) explained that team tenure is the length of time an individual has been with the team. When predicting team outcomes, researchers considered team tenure as an important compositional factor (Katz, 1982). Team tenure is highlighted critically in classic theories of group development and effectiveness either explicitly or implicitly. The most common assumption in that is greater the team tenure, teams are more effective (Finkelstein \& Hambrick, 1990; Marks, Mathieu \& Zaccaro, 2001). Furthermore, in team research tenure is mostly used as a control variable and highlighted researchers emphasis on team tenure for team performance (Bernerth \& Augins, 2016). Practically managers who are looking to staff teams to maximize their effectiveness, information of team tenure effects on team performance is critical (Gonzalez, Mule, Cockburn, McCormick \& Zhao, 2020).

Koopmann, Lanji, Wang, Zhou and Shi, (2016, p.941) emphasized that team tenure is regarded as a fundamental team compositional factor for team effectiveness but it is unclear that team tenure implications on the team performance. Many scholars have discussed this sentiment (Ilgen, Hollenbeck, Johnson \& Jundt, 2005; Mathieu, Maynard, Rapp \& Gilson, 2008).

Chan, (1998) emphasized that team tenure can be conceptualized in terms of an additive model (all team members average tenure), a collective model (all team members shared tenure), or a dispersion model (heterogeneity of individual team members' tenure). This conceptualization of each team tenure have unique theoretical propositions associated with them and their influence on team performance may differ (De Rue, Hollenbeck, Ilgen \& Feltz, 2010). 
Hence, there is a lack of literature leads some studies showing a negative relationship between team tenure and team performance (Katz, 1982) and some studies showing relationship to zero (Buderson \& Sutcliffe, 2003). Furthermore, other studies found that there is a positive relationship between team tenure and team performance (Zhang, Waldman \& Wang, 2012).

This varying effect shows an opportunity to progress research on team tenure. Many research studies operationalize tenure based on additive composition model but provide a theoretical explanation based on shared experience to explain the relationship between team tenure and team performance (Gonzalez, Mule, Cockburn, McCormick \& Zhao, 2020).

\section{Team Trust and Team Performance Relationship}

Mayers et al, (1995) organizational trust model emphasize that outcomes are generated through risk-taking behaviour with interdependent relationship consist of trust (Mayer et al, 1995). In here trusting party engage in a range of cooperative behaviours like task delegation, supporting the process of change and recognize ability, benevolence and integrity of another party (Kisamore \& Morissette, 2020). The team can achieve their goals through this collective and complaint behaviours. Furthermore, teams can foster their cooperation, which helps to the accomplishment of team members shared team task by successfully develop their trust (Kisamore \& Morissette, 2020). Team trust is regarded as one of an interesting topic for marketing and management scholars and emphasizes that trust is a function of high team output (eg. decision, product) quality. (Akgun et al., 2005; Dayan Di Benedetto, 2010; Muethel et al, 2012). According to Dayan and Di Benedetto (2010: p. 699) team trust plays a crucial role in new product performance. They argued that team members develop new products with fewer technical problems, find and solve customer dissatisfied product problem areas as team members develop trust (Dayan \& Di Bendetto, 2010). Dayan and Di Bendetto, (2010) found that higher the team trust there is high success in new products. Furthermore, many recent studies show that there is a positive, large correlation between team trust and team performance (Buvik \& Tuedit, 2016, Chou et al, 2013; Lee et al, 2015).

Chen, Cui, Ma, Su and Yang, (2020) mentioned that intra organizational trust in team level is considered a collection of trust among team members. In a general way trust support for the improvement of team performance and there are different dimensions of trust that impact team performance in different ways (Braun et al, 2013). When we consider about the relationship perspective team trust will help to remove doubts among team members, encourage themselves to carry out activities that contribute to team performance and work more effectively together (De-jong and Elfring, 2010). Due to team members more willingly accept work arrangements, the team will form professional and complementary knowledge and skills to complete tasks. Furthermore, team members freely share their ideas with each other and exchange their own experience and effective information that will help to improve team innovation and new product development performance due to the mutual trust among team members (Akgun et al, 2005).

Team trust develops conditions like commitment, quality, comprehension and emotional acceptance of decision making, which helps for efficient decision making further than helping to attain effective communication and cooperation within a team (Chen, Cui, Ma, Su \& Yang, 2020). Trust initially improve the team membership then develops knowledge and ability and finally helps for creative ideas. (Chen, Cui, Ma, Su \& Yang, 2020).

H1: There is a significant impact of team trust on team performance. 


\section{Team Tenure and Team Trust}

Some research has emphasized that longer team tenure improve trust within teams (Katz, 1982; Michael \& Hambrick, 1992; Smith et al, 1994). Hence, to improve trust team members need to become comfortable and to identify with their team members. In order to achieve that team members need time to process. (Harrison et al, 2003; Pelled, Eisenharat \& Xin, 1999). In traditional literature emphasized that teams with short tenure are more likely to have lower team psychological safety climate because of mistrust as a negative interpersonal experience

(Edmonsdon, 1999, Wikens \& London, 2006). As vice versa, long-tenured teams have accumulated trust as a positive interpersonal exchange, which results in a higher team psychological safety climate (Edmondson, 1999). When looking on the social identity perspective explained in, group formation theories (Tajfel \& Turner, 1979) described that when a team is firstly established they form team perceptions and experience high trust levels (Prentice, Miller \& Lightdale, 1994). In newly formed teams, their lack of data for team members understands the trustworthiness of their teammates. Even though common group identity help to form high initial trust, personal data gathering is considered as a difficult task to judge the trustworthiness of teammates (Mcknigh et al, 1998, Meyerson et al, 1996).

The initial team perception to build trust within a team is based on shared group membership that promotes similarity-based attraction among group members and reinforces distinctiveness between current group and other groups (Hogs \& Terry, 2000); Tajfel \& Turren, 1979). This process of self-categorization promote team members common group identity and positive interpersonal experiences.

Furthermore, Turner (1982) argued that mere forming of the team serves as a valid cause to team members to depersonalize the self and other members and to consider them as a whole, which results in mutual trust and reliance among team members.

$\mathrm{H} 2$ : There is a significant impact of team tenure on team trust

\section{Team Tenure and Team Performance Relationship}

Meta-analysis studies emphasized that team tenure and team performance relationship is still inconclusive (Bel et al, 2011), even though some researchers argued that team tenure positively impact the team performance (Kozlowski et al, 1999). Tenured teams focus on task performance by reducing process losses and developing coordination mechanism than a newly formed team who use more time to acquire interpersonal information (Harrison et al, 2003).

Pelled et al, (1999) explained that team members will develop a shared understanding of tasks and learn to anticipate others reactions.

Furthermore, Hirst, (2009) suggested that team members become specialized, develop common perspectives and share their knowledge due to tenure. Some researchers argued that tenure has a negative side (Abrantes, Mach \& Ferreira, 2020).

Berman, Down and Hill, (2002) found that through tacit knowledge accumulation tenure positively impact team performance and this conclusion derived using data gathered from the American National Basketball Association. However, Abrantes, Mach and Ferreira, (2020) argued that knowledge ossification may occur because of shared experience and it may out weight the benefits of collective knowledge accumulation by negative effects on performance. Which means the value of tacit knowledge declines over time, it leads to knowledge ossification. Knowledge ossification leads to process routinisation around forms of team member 
interaction and teams' ability to perform in dynamic environments will be limited (Abrantes, Mach and Ferreira, 2020).

Katz, (1982) argued that team tenure and team performance has a nonlinear relationship and explained that teams become less adaptive and innovative for teams working a long time together Since team members might increasingly be relying on the groups own expertise. In the end, the impact of team tenure on team performance decided on the extent to which it translates into constructive interpersonal interactions based on social acceptance and trust (Koopmann et al, 2016). Koopmann, Lani, Wang Zhou and Shi, (2016) emphasized that there is a curvilinear relationship between team tenure and team member creative performance as partially mediated by team psychological safety climate. Furthermore, they explained strong team psychological safety climate improve team member task performance. Therefore, team tenure has curvilinear manner impact on an average team member, task performance.

H3: There is a significant impact of team tenure on team performance.

H4: Team tenure moderates the relationship between team trust and team performance.

The hypothesized relationship among the said variables are depicted in figure 1 ; the conceptual framework of the study.

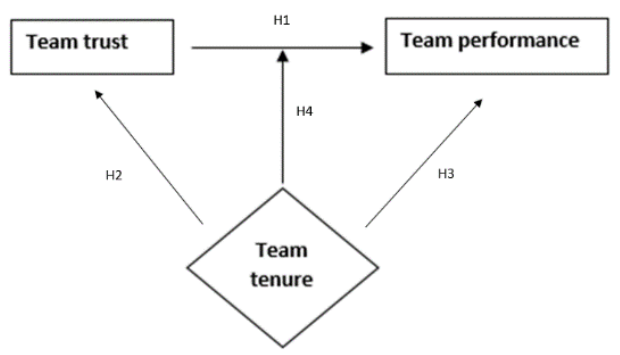

Figure 01: The Conceptual Framework of the Study

\section{Research Methodology}

This is a cross- sectional study. The unit of analysis is the individual executive level employees in tyre manufacturing industry. Out of the 192 questionnaires distributed to four major tyre manufacturers in Sri Lanka, 141 questionnaires were returned (response rate of $73.43 \%$ ). Of those returned, only 135 questionnaires were in a usable state (effective response rate of $70.31 \%$ ). The researchers employed simple random sampling technique and the data collection was done through a self-administered through an online questionnaire survey, designed as a google form. After the data collection was performed, data were analysed using SPSS version 21. Then the data were tested to ensure normality, linearity, validity, reliability, correlation, regression analysis, one way ANOVA and process matrix.

\section{Measures}

Adopting the measurement scale developed by Costa \& Anderson, (2011) team trust was assessed through four dimensions; propensity to trust, perceived trustworthiness, cooperative behaviours and monitoring behaviours. The variable 'team performance' was assessed using the adapted scales taken from Pinto, (1990). Team performance was operationalized through two dimensions; communication and trouble - shooting. In addition team tenure was assessed by requesting employees to select a range of years they had worked on their team (Schippers et al, 2003).

\section{Population, Sample and the Sampling Technique}

Due to the prevailing Covid 19 pandemic situation, the data about population is obtained by HR departments of respective tyre manufacturing organizations and the mode of communication is telephone calls. Population is consist of executive level employees of four major tyre manufacturing organizations, which is total of 383 . The sample size is 192 according to Mogan table 
with 0.05 margin of error. (Krejcie \& Morgan, 1970) and simple random sampling technique is used for data gathering.

\section{Sample Composition}

The sample consisted of 124 executive level employees in tyre manufacturing industry after 11 outliers are removed. Most (44.4\%) belonged to the age category of 25-34 years, while very few $(8.9 \%)$ employees belonged to the age category of 45-54 years. Majority $(81.5 \%)$ of the employees were male. Most of the executive level employees $(37.1 \%)$ had 12 years of team tenure and $(36.3 \%)$ service period of 1-2 years with in there organization. The four major tyre manufacturers were given hypothetical names ( $\mathrm{W}, \mathrm{X}, \mathrm{Y} \& \mathrm{Z}$ ).

\section{Results}

Sample adequacy and the sphericity were ensured through the Kaisen-Meyer-Olkin (KMO) Measure and the Bartlett's test respectively. According to the intial validity statistics three items were removed in the data analysis since, cumulative percentage of the Extraction Sums of Squared Loadings (ESSL Cum\%) is loaded into two components in two dimensions of independent variable team trust and to ensure the validity of the data set. After removing three items from the data set KMO coefficient is greater than 0.7 for both variables, and the Sig. value is less than 0.05 , statistically, it is claimed that the study sample of 124 observations is adequate enough to proceed with EFA. Also, results indicate that sufficient correlation exists among the variables to proceed, and in this study, therefore, sampling adequacy is significant. Since the KMO measure of sampling adequacy meets the minimum criteria, there is no need to examine the AntiImage Correlation Matrix. Results of the $\mathrm{KMO}$ and the Bartlett's test are given in table 2. See Appendix B

According to the validity statistics given in table 3, the cumulative percentage of the Extraction Sums of Squared Loading (ESS cum\%) of two constructs are greater than $50 \%$, and the item Factor Loading (FL) values are above the threshold limit of 0.5 as recommended by Hair, Black, Babin, \& Anderson, (2010). So that, statistically, the construct validity is ensured. See Appendix C.

To ensure the reliability of measurement scales, internal consistency statistics were used. As recommended by Nunnally (1978) and Lu et al., (2007) construct reliability and dimension reliability were assessed using Cronbach's Alpha coefficient. In this study as shown in table 4, Cronbach's Alpha values of all variables dimensions are greater than 0.7 including that the multi-item scales are reliable, and all the items have played a significant role in conceptualizing the respective constructs. The Cronbach's alpha value of Team Trust is 0.831 and Team Performance is 0.892 . Team tenure is a categorical variable. Hence, it does not analysed for Cronbach's Alpha coefficient. See Appendix D.

There are basic measures of descriptive statistics widely used in social science research; mean and standard deviation. If the value of standard deviation falls between -2 and +2 , the variability of the construct is said to be accepted for further statistical analyses (Lu et al., 2007) (Tables 5). See Appendix E.

According to the results of the One-Sample Kolmogorov-Smirnov Test for Normality, the Asymp. Sig. Values of the construct 'team performance' is 0.168 . In accordance with the basic decision-making rule of the normality test, as the Asymp. Sig. Values obtained for construct is greater than 0.01 , it is that the data series of team performance is normally distributed. The value sig. of deviation from linearity is 0.077 which is greater than 0.05 .

Thus, it could be concluded that is a linear relationship between the constructs of team trust and team performance. Building on the linear relationship found among the team trust and team performance, the Pearson 
Correlation Coefficient was used to assess the strength of association among the said two constructs. Further, Sig. (2-tailed) the test was applied to test the significance of the correlation coefficient. Results of the correlation analysis are given in table 6. See Appendix F.

According to table 6, a strong positive correlation is found between team trust and team performance $(\mathrm{r}=0.721)$ which is statistically significant as the level of significance $(0.000)$ is less than the Sig. 1 tailed (0.001). Hence, team trust is significantly correlated with team performance (Kisamore \& Morissette, 2020).

\section{Hypotheses Testing}

For the current study, regression analysis, one way ANOVA and Andrew F. Hayes process matrix were employed to test the hypotheses. Linear regression analysis was done to test the hypothesis advanced for the impact of team trust on team performance. According to the results depicted in Table 7, shows that R Square is .521. Therefore, team trust explains a $52.1 \%$ variance in team performance. According to the results depicted in Table 8, a variation of team performance could be significantly (Sig. = 0.00 which is less than 0.05 ) explained by the independent construct in the research model; team trust. Further, as given in table 9, the marginal contribution of team trust $(0.824)$ in determining the impact on team performance is to be considered statistically significant $(\mathrm{Sig} .=0.00)$ in the regression equation. Thus, according to the regression results, $\mathrm{H} 1$ is accepted statistically claiming that there is a positive impact of team trust on team performance.

One-way ANOVA test was done to test the hypothesis advanced for the impact of team tenure on team trust and the impact of team tenure on team performance.

Hence, team tenure is considered as a categorical variable, one-way ANOVA test was conducted to test the hypotheses.
According to the results of the One-way ANOVA test depicted in table 10, the Sig. Value of the construct 'team trust' is 0.127 . In accordance with the basic decisionmaking rule of the one-way ANOVA test, as the Sig. Value obtained for construct is greater than 0.05 , that the categorical variable, team tenure is considered as insignificant. Therefore, the $\mathrm{H} 2$ is rejected which is team tenure does not significantly impact on team trust. According to the results of the One-way ANOVA test depicted in table 11, the Sig. Value of the construct 'team performance' is 0.857. In accordance with the basic decision-making rule of the oneway ANOVA test, as the Sig. Value obtained for construct is greater than 0.05 , that the categorical variable, team tenure is considered as insignificant. Therefore, the $\mathrm{H} 3$ is rejected which is team tenure does not significantly impact on team performance.

Andrew F. Hayes process matrix analysis model 01 (2018), was done to test the hypothesis (H4) advanced for the test of team tenure significant moderating relationship between team trust and team performance. In the Linear regression analysis was done to the test the direct effect of the independent and dependent variables. According to the result of that, there is a positive impact of team trust on team performance. Result of process matrix test is given in table 12. According to the Andrew F. Hayes process matrix (2018), if the model is significant, zero should not be in between LICI and ULCI. That is both values must be positive or negative.

However, as per the table 12 , the ' 0 ' is located between LICI and ULCI under Team Tenure row. That is LICI and ULCI values are negative and positive (LICI $=-0.8343$ ) $(\mathrm{ULCI}=0.3727)$. Thus according to the process matrix results hypothesis $(\mathrm{H} 4)$ is rejected statistically claiming that team tenure is not significantly moderate the relationship between team trust and team performance. See Appendix G, H, I, J, K and L.

\section{Discussion}

Kelaniya Journal of Management | 2021 | Vol. 10 | Issue 02 | Page 127 
In the current study, a significant impact is found from the team trust on team performance. Irrespective of the contextual differences, this result is in line with and supported by many of the previous studies. As stated by Kisamore and Morissette, (2020), team trust - team performance relationship was positive and large in magnitude. Similarly, they have reported that business leaders should understand that the shared perception of trust within a team may foster higher levels of team performance. Moreover, teams can foster their cooperation, which facilitates them to attain their shared team task by successfully develop their trust (Kisamore \& Morissette, 2020). Furthermore, De-jong and Elfring (2010) found that the relationship perspective team trust will help to remove doubts among team members, encourage themselves to carry out activities that contribute to team performance, which is in line with the current findings.

Although team tenure act as a moderating variable in this study, it is used as an independent variable and its impact on team trust and team performance separately. The findings show that team tenure does not significantly impact on team trust. Which means team tenure is not a significant predictor of team trust. Team members who have any team tenure can have high or low trust within the team. This result is different from previous studies, which indicate that longer team tenure improves trust within teams (Katz, 1982, Michael \& Hambrick, 1992). Furthermore, researchers like Edmonsdon, (1999) emphasized that teams with short tenure are more likely to have lower team psychological safety climate because of mistrust as a negative interpersonal experience.

The impact of team tenure on team performance is founded to be insignificant in this study, Which mean team tenure is not a significant predictor of team performance. Team members who have any tenure within the team will equally perform better. Even though some previous studies argued that team tenure positively impact on team performance (Kozlowski et al, 1999). However, this finding is in line with the Bel et al, (2011) conclusion, which is the relationship between team tenure and team performance is inconclusive. Some researchers like Abrantis, Mach \& Ferreira, (2020) explained that team tenure has a negative side. The executive level employees in Sri Lankan tyre manufacturing industry team tenure does not significantly impact team performance.

This study examined the moderating impact of team tenure on team trust - team performance relationship in Sri Lankan tyre manufacturing industry. Which is the originality of the study findings shows that team tenure does not significantly moderate the relationship between team trust and team performance. The above findings reveal that team tenure does not significantly impact team trust and team performance separately. Furthermore, as suggested by Kisamore and Morissette, (2020). How team tenure as a moderator impact team trust and team performance relationship found to be insignificant in Sri Lankan tyre manufacturing industry executive level employees with these results.

In current study findings from data analysis were $\mathrm{R}=0.721$ and $\mathrm{R}$ square $=0.521$. The result clearly revealed that there is a positive impact on team trust and team performance. Finally, the researcher found from the current study team trust has $52.1 \%$ impact on team performance in Sri Lankan tyre manufacturing industry executive level employee teams.

\section{Limitations}

The sample of the study was four major tyre manufacturing organizations and only so one of the limitations is related to the sample which the researchers expected to select. The researchers collected data using a startified random sample. And it confined to only those four major organization. Therefore, the data and findings may not be representative of the 
whole Sri Lankan context, which is identified as another limitation of the study. Another limitation is in collecting data through google form with the effect of COVID 19 pandemic situation. It resulted in fewer response rate comparing to the sample size. In addition, the researcher used the questionnaire as the only technique to collect data.

Therefore, these data may be more quantitative and questionnaires might be unable to gather the inner feelings of the respondents. Organizations that included in the sample did not approve to cite their name in the population details. Therefore, the researcher used assumed names in order to give the population statistics. It is considered as a limitation in this study.

\section{Conclusion}

Having considered the findings of the current study, it could be concluded that team trust significantly correlated with team performance of the tyre manufacturing industry. And also, a positive impact is found from team trust on team performance in Sri Lankan tyre manufacturing industry. Furthermore, it was identified that team tenure does not impact team trust and team performance separately. When considering team tenure, it does not improve or weaken the relationship between team trust and team performance according to the research findings. It is provided that a high level of team trust in every aspect leads to high team performance. This chapter also presented the possible limitations of this study. Some recommendations are also offered with regard to future research in this field within the Sri Lankan context.

\section{Recommendations}

Building on the above-reported conclusions, it is recommended to facilitate more open communication and information sharing in order to improve trust in teams to get the outcome of better team performance. And also, it is recommended to have informal gatherings once a week to improve trust within teams. In addition, it is recommended to have sports events in team levels to participate with team members and develop their trust. Furthermore, using outbound training as a medium to develop trust within the team. It is recommended use by policymakers. Top management should concern trust as a core value of the firm in order to uplift performance within teams.

A team member who recently joins the team or a member who has a long history with the team should not concern their tenure and recommended to engage with activities like above-mentioned sports events to develop trust with other team members. In order to improve the trust within the team it is recommended facilitate more collective activities and less monitoring activities within the team. 
Rajapaksha B.P., Nishanthi H.M., KJM, 2021, 10 (02)

\section{References}

Abrantes, A. C., Mach, M., \& Ferreira, A. I. (2020). Tenure matters for team cohesion and performance: the moderating role of trust in the coach. European Sport Management Quarterly, 1-22. https://doi.org/10.1080/16184742.2020.1784247

Akgün, A. E., Byrne, J., Keskin, H., Lynn, G., \& Imamoglu, S. Z. (2005). Knowledge networks in new product development projects: a transactive memory perspective. Information and Management, 42(8), 1105-1120. https://doi.org/10.1016/j.im.2005.01.001

Bell, S. T., Villado, A. j., Lukasik, M. A., Belau, L., \& Briggs, A. L. (2011). Getting specific about demographic diversity variable and team performance relationships: A meta-analysis. Journal of Management, 37(3), 709-743. https://doi.org/10.1177/0149206310365001

Berman, S. L., Down, J., \& Hill, C. W. (2002). Tacit knowledge as a source of competitive advantage in the National basketball Association. Academy of Management Journal, 45, 13 31.https://doi.org/10.5465/3069282

Bernerth, J. B., \& Aguinis, H. (2016). A critical review and best-practice recommendations for control variable usage. Personnel Psychology, 69, 229-283. https://doi.org/10.1111/peps.12103

Blau, P. (1964). Exchange and Power in Social Life. John Wiley and Sons.

Braun, S., Peus, C., Weisweiler, S., \& Frey, D. (2013). Transformational leadership, job satisfaction, and team performance: a multilevel mediation model of trust. The Leadership Quarterly, 24(1), 270-283. https://doi.org/10.1016/j.leaqua.2012.11.006

Breuer, C., Hüffmeier, J., \& Hertel, G. (2016). Does trust matter more in virtual teams? A meta-analysis of trust and team effectiveness considering virtuality and documentation as moderators. Journal of Applied Psychology, 101(8), 1151-1171. https://doi:10.1037/ap10000113

Bunderson,, J. S., \& Sutcliffe, K. M. (2003). Management team learning orientation and business unit performance. Journal of Applied Psychology, 88, 552-560. https://doi.org/10.1037/0021-9010.88.3.552

Buvik, M. P., \& Tvedt, S. D. (2016). The impact of commitment and climate strength on the relationship between trust and performance in cross-functional project teams: a moderated mediation analysis. Team Performance Management: An International Journal, 22(3/4), 143. https://doi:10.1108/TPM-02-2015-0011

Carter, N., Carter, D., \& DeChurch, L. (2018). Implications of observability for the theory and measurement of emergent team phenomena. Journal of Management, 44(4), 1398-1425. https://doi:10.1177/0149206315609402

Chan, D. (1998). Functional relations among constructs in the same content domain at different levels of analysis: A typology of compositionmodels. Journal of Applied Psychology, 83, 234-246. https://doi.org/10.1037/0021-9010.83.2.234 
Rajapaksha B.P., Nishanthi H.M., KJM, 2021, 10 (02)

Chou, H. W., Lin, Y. H., Chang, H. H., \& Chuang, W. W. (2013). Transformational leadership and team performance. SAGE Open, 3(3), 1-10. doi:10.1177/2158244013497027

Clark, M. C., \& Payne, R. L. (1997). The nature and structure of worker's trust in management. Journal of Organizational Behaviour, 18(3), 205-224. https://doi.org/10.1002/(SICI)1099-1379(199705)18:3<205::AID-JOB792>3.0.CO;2-V

Costa, A.C. (2003), "Work team trust and effectiveness", Personnel Review, 32(5), 605-622. https://doi.org/10.1108/00483480310488360

Costa, A. C., \& Anderson, N. (2011). Measuring trust in teams : Development and validation of a multifaceted measure of formative and reflective indicators of team trust. European Journal of Work and Organizational Psychology, 20(1), 119-154. https://doi.org/10.1080/13594320903272083

Costa, A. C., Roe, R. A., \& Taillieu, T. (2001). Trust within teams: The relation with performance effectiveness. European Journal of Work and Organizational Psychology, 10(3), 225-244. https://doi.org/10.1080/13594320143000654

Cummings, L. L., \& Bromiley, P. (1996). The organizational trust inventory (OTI). Trust in organizations: Frontiers of theory and research, 302(330), 39-52.

Currall, S. C., \& Judge, T. H. (1995). Measuring trust between organizational boundary role persons. Organizational Behavior and Human Decision Process, 64(2), 151-170. https://doi.org/10.1006/obhd.1995.1097

Das, T. K., \& Teng, B. S. (1998). Between Trust and Control: Developing Confidence in Partner Cooperation in Alliances. Academy of Management Review, 23(3). https://doi.org/10.5465/amr.1998.926623

Dasgupta, P. (1988). Trust as a Commodity, 49-72. In Diego Gambetta (ed.), Trust: Making and Breaking Cooperative Relations. Blackwell.

Dayan, M., \& Di Benedetto, C. A. (2010). "The impact of structural and contextual factors on trust formation in product development teams". Industrial Marketing Management, 39(4), 691-703. doi:10.1016/j.indmarman.2010.01.00

De Jong, B. A., Dirks, K. T., \& Gillespie, N. (2016). "Trust and team performance: a metaanalysis of main effects, moderators and covariates ". Journal of Applied Psychology, 101(8), 11341-1150. doi:10.1037/ap10000110

De-Jong, B. A., \& Elfring, T. (2010). "How does trust affect the performance of ongoing teams? The mediating role of reflexivity, monitoring, and effort". Academy of Management Journal, 53(3), 535-549. https://doi.org/10.5465/amj.2010.51468649

DeRue, D. S., Hollenbeck, J., Ilgen , D., \& Feltz, D. (2010). Efficacy dispersion in teams: Moving beyond agreement and aggregation. Personnel Psychology, 63, 1-40. Retrieved from https://doi.org/10.1111/j.1744-6570.2009.01161.x 
Rajapaksha B.P., Nishanthi H.M., KJM, 2021, 10 (02)

Dionne, S. D., Yammarino, F. J., Atwater, L. E., \& Spangler, W. D. (2004). Transformational leadership and team performance. Journal of organizational change management, 17(2), 177 193. https://doi.org/10.1108/09534810410530601

Edmondson, A. C. (1999). Team psychological safety and learning behavior in work teams. Administrative Science Quarterly, 44, 350-383. http://dx.doi.org/10.2307/2666999

Edmondson, A. C. (2002). The local and variegated nature of learning in organizations: a group-level perspective. Organization Science, 13(2), 128-146. https://doi.org/10.1287/orsc.13.2.128.530

Erdem, F., Ozen, J., \& Atsan, N. (2003). The relationship between trust and team performance. Work Study, 52(7), 337-340. https://doi.org/10.1108/00438020310502633

Farris, G. F., Senner, E. E., \& Butterfield, D. A. (1973). Trust, Culture, and Organizational Behavior. A Journal of Economy and Society. https://doi.org/10.1111/j.1468232X.1973.tb00544.x

Finkelstein, S., \& Hambrick, D. C. (1990). Top-management-team tenure and organizational outcomes: The moderating role of managerial discretion. Administrative science quarterly, 484-503. https://doi.org/10.2307/2393314

Fulmer, C. A., \& Gelfand, M. J. (2012). “At what level (and in whom) we trust: trust across multiple organizational levels". Journal of Management, 38(4), 1167-1230. doi: $10.1177 / 0149206312439327$

Dasgupta, P., \& Gambetta, D. (1988). Trust: Making and breaking cooperative relations. Department of Sociology, University of Oxford: Basil Blackwell, 49-72

Gillespie, N. A., \& Mann , L. (2004). Transformational leadership and shared values: the building blocks of trust. Journal of Managerial Psychology, 19(6), 588-607. Retrieved from https://doi.org/10.1108/02683940410551507

Gonzalez-Mulé, E. S., Cockburn, B. W., McCormick, B., \& Zhao, P. (2020). Team tenure and team performance: A meta-analysis and process model. Personnel Psychology, 73(1), 151198. https://doi.org/10.1111/peps.12319

Hair, J. F., Black, W. C., \& Babin, B. J. ve Anderson, RE (2010). Multivariate Data Analysis: A Global Perspective.(7th edition). Pearson publishing.

Harrison, D. A., Mohammed, S., McGrath, J. E., Florey, A. T., \& Vanderstoep, S. W. (2003). Time matters in team performance: Effects of member familiarity, entrainment, and task discontinuity on speed and quality. Personnel Psychology, 56(3), 633-669. Retrieved from https://doi.org/10.1111/j.1744-6570.2003.tb00753.x

Hirst, G. (2009). Effects of membership change on open discussion and team performance: The moderating role of team tenure. European Journal of Work and Organizational Psychology, 18(2), 231-249. https://doi.org/10.1080/13594320802394202 
Hogg, M. A., \& Terry, D. J. (2000). Social identity and self-categorization processes in organizational contexts. The Academy of Management Review, 25, 121-140.

Ilgen, D. R., Hollenbeck, J. R., Johnson, M., \& Jundt, D. (2005). Teams in organizations: From input-process-output models to IMOImodels. Annual Review of Psychology, 56, $517-$ 543. Retrieved from https://doi.org/10.1146/annurev.psych.56.091103.070250

Inkpen, A., Currall, S., Beamish, P. W., \& Kiling, J. P. (1997). International Joint Venture Trust: An Empirical Examination in Cooperative Strategies. 1. North American Perspectives. New Lexington Press.

Jaakson, K., Reino, A., \& McClenaghan, P. B. (2019). The space between - linking trust with individual and team performance in virtual teams. Team Performance Management, 25(1/2), 30-46. Retrieved from https://doi.org/10.1108/TPM-03-2018-0024

Jones, R., \& George, J. (1998). The evolution of trust and cooperation: implication for teamwork and tacit knowledge. Academy of Management Review, 23(2), 531-461.

Katz, R. (1982). The effects of group longevity on project communication and performance. Administrative Science Quarterly, 27(1), 81-104. Retrieved from https://doi.org/10.2307/2392547

Kirkman, B. L., \& Shapiro, D. L. (1997). The impact of cultural values on employee resistance to teams: Toward a model of globalized self-managing work team effectiveness. Academy of Management Review, 22(3), 730-757.

Kisamore, J. L., \& Morrissette, A. M. (2020). Trust and performance in business teams: a meta-analysis. Team Performance Management, 26(5/6), 287-300. Retrieved from https://doi.org/10.1108/TPM-02-2020-0012

Koopmann, J., Lanaj, K., Wang, M., Zhou, L., \& Shi, J. (2016). Nonlinear effects of team tenure on team psychological safety climate and climate strength: Implications for average team member performance. Journal of Applied Psychology, 101(7), 940-957. Retrieved from https://doi.org/10.1037/ap10000097

Kozlowski, S. J., Gully, S. M., Nason, E. R., \& Smith, E. M. (1999). Developing adaptive teams: A theory of compilation and performance across levels and time. In D. R. Ilgen, \& E. D. Pulakos (Eds.), The Changing Nature of Performance: Implications for Staffing, Motivation, and Development (pp. 240-292). Wiley.

Kozlowski, S. W., \& Bell, B. S. (2003). Work Groups and Teams in Organizations (Vol. 12). Retrieved from https://doi.org/10.1002/9781118133880.hop212017

Kozlowski, W. S., \& Ilgen, R. D. (2006). Enhancing the Effectiveness of Work Groups and Teams. 7(3), 77-124. Retrieved from https://doi.org/10.1111\%2Fj.1529-1006.2006.00030.x

Kramer, R. M. (1999). Trust and distrust in organisations: Emerging Perspectives, Enduring Questions. Annual Review of Psychology, 50, 569-598. Retrieved from https://doi.org/10.1146/annurev.psych.50.1.569 
Rajapaksha B.P., Nishanthi H.M., KJM, 2021, 10 (02)

Krejcie RV, Morgan DW. Determining Sample Size for Research Activities. Educational and Psychological Measurement. 1970;30(3):607-610. doi:10.1177/001316447003000308

Langfred, C. W. (2004). Too Much of a Good Thing? Negative Effects of High Trust and Individual Autonomy in Self-Managing Teams. Academy of Management Journal, 47(3). Retrieved from https://doi.org/10.5465/20159588

Lee, J., Park, J. G., \& Lee, S. (2015). "Raising team social capital with knowledge and communication in information systems development projects". International Journal of Project Management, 33(4), 797-807. doi:10.1016/j.ijproman.2014.12.001

Leifer, R., \& Mills, P. K. (1996). An information processing approach for deciding upon control An information processing approach for deciding upon control strategies and reducing control loss in emerging organizations. Journal of Management, 22(1), 113-137. Retrieved from https://doi.org/10.1016/S0149-2063(96)90014-8

Lewicki, R. J., \& Bunker, B. B. (1996). Developing and maintaining trust in work relationships. In R. M. Kramer , \& T. R. Tyler (Eds.), Trust in organizations: Frontiers of theory and research (pp. 114-139). Thousand Oaks, CA: Sage.

Lewis, J. D., \& Weigert, A. (1985). Trust as a Social Reality. Social Forces, 63(4), 967-985. Retrieved from https://doi.org/10.1093/sf/63.4.967

Lin, C., Standing, C., \& Liu, Y. C. (2008). A model to develop effective virtual teams. Decision Support Systems, 45(4), pp.1031-1045. https://doi.org/10.1016/j.dss.2008.04.002

Mach, M. \& Baruch, Y. (2015), Team performance in cross cultural project teams: The moderated mediation role of consensus, heterogeneity, faultlines and trust, Cross Cultural Management: An International Journal, 22(3), 464-486. https://doi.org/10.1108/CCM-102014-0114

Manz, C.C. \& Neck, C.P. (1995), Teamthink: beyond the groupthink syndrome in selfmanaging work teams, Journal of Managerial Psychology, 10(1), 7-15. https://doi.org/10.1108/02683949510075155

Mathieu, J. E., Marks, M. A., \& Zaccaro, S. J. (2001). Multisystem teams. Handbook of Industrial, work and organizational psychology, 289-313.

Mathieu, J., Maynard, M. T., Rapp, T., \& Gilson, L. (2008). Team effectiveness 1997-2007: A review of recent advancements and a glimpse into the future. Journal of Management, 34, 410-476. Retrieved from https://doi.org/10.1177/0149206308316061

Mayer, R. C., Davis , J. H., \& Schoorman, F. D. (1995). An Integrative Model Of Organizational Trust. Academy of Management Review, 20(3). Retrieved from https://doi.org/10.5465/amr.1995.9508080335

McAllister, D. J. (1995). Affect- and Cognition-Based Trust as Foundations for Interpersonal Cooperation in Organizations. Academy of Management Journal, 38(1). Retrieved from https://doi.org/10.5465/256727 
Rajapaksha B.P., Nishanthi H.M., KJM, 2021, 10 (02)

McGrath, J. E. (1984). Group Interaction and Performance. Prentice-Hall,.

McKnight, D. H., Cummings, L. L., \& Chervany, N. L. (1998). Initial trust formation in new organizational relationships. The Academy of Management Review, 23(3), 473-190. https://doi.org/10.5465/amr.1998.926622

Mesmer-Magnus, J. R., \& DeChurch, L. A. (2009). Information sharing and team performance: A meta-analysis. Journal of Applied Psychology, 94(2), 535-546. https://doi.org/10.1037/a0013773

Meyerson, D., Weick, K. E., \& Kramer, R. M. (1996). Trust in organizations: Frontiers of theory and research. (R. M. Kramer , \& T. R. Tyler, Eds.) Thousand Oaks, CA: Sage. Retrieved from http://dx.doi.org/10.4135/9781452243610.n9

Michel, J. G., \& Hambrick, D. C. (1992). Diversification posture and top management team

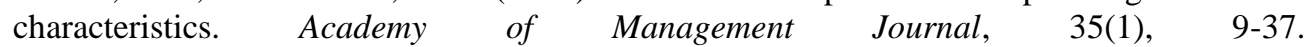
http://dx.doi.org/10.2307/256471

Muethel, M., Siebdrat, F., \& Hoegl, M. (2012). "When do we really need interpersonal trust in globally dispersed new product development teams?". R\&D Management, 42(1), 31-46. doi:10.1111/j.1467-9310.2011.00667.x.

Nooteboom, B. (2002). Trust: Forms, foundations, functions, failures and figures. Edward Elgar Publishing.

Nunnally, J. C. (1978). Psychometric Theory (2nd ed.). Mcgraw hill book company. http://hdl.handle.net/123456789/11061

Pathirage, Y. D., Jayawardena, L. N., \& Rajapaksha, T. N. (2012). Impact of management support for team performance: a Sri Lankan case study in apparel industry. Tropical Agricultural Research. 23(3): 228 - 236. Retrieved from tar.sljol.info

Pelled, L. H., Eisenhardt, K. M., \& Xin, K. R. (1999). Exploring the black box: An analysis of work group diversity, conflict and performance. Administrative Science Quarterly, 44(1), 1-28. Retrieved from https://doi.org/10.2307/2667029

Peters, L. M., \& Manz, C. C. (2007). Identifying antecedents of virtual team collaboration. $\begin{array}{llll}\text { Team Performance } & \text { Management, } & 13(3 / 4), & 117-129 .\end{array}$ https://doi.org/10.1108/13527590710759865

Pinto, J. K. (1990). Project Implementation Profile: a tool to aid project tracking and control. International Journal of project management, 8(3), 173-182. https://doi.org/10.1016/02637863(90)90020-C

Prentice, D. A., Miller, D. T., \& Lightdale, J. R. (1994). Asymmetries in attachments to groups and their members: Distinguishing between common-identity and common-bond groups. Personality and Social Psychology Bulletin, 20, $484-493$. http://dx.doi.org/10.1177/0146167294205005 
Rajapaksha B.P., Nishanthi H.M., KJM, 2021, 10 (02)

Puusa, A., \& Tolvanen, U. (2006). Organizational Identity and Trust. EJBO - Electronic Journal of Business Ethics and Organizational Studies, 11(2). http://urn.fi/URN:NBN:fi:jyu201010042895

Rotter, \& Julian, B. (1967). A new scale for the measurement of interpersonal trust. Journal of Personality, 35(4), 651-665. Retrieved from https://doi.org/10.1111/j.14676494.1967.tb01454.x

Rotter, J. B. (1980). Interpersonal trust, trustworthiness, and gullibility. American Psychologist, 35(1), 1-7. https://doi.org/10.1037/0003-066X.35.1.1

Salas, E., Rosen, M. A., Burke, C. S., \& Goodwin, G. F. (2009). The wisdom of collectives in organizations: An update of the teamwork competencies. In E. Salas, G. F. Goodwin, \& C. S. Burke (Eds.), Team effectiveness in complex organizations: Cross-disciplinary perspectives and approaches (pp. 39-79). Routledge/Taylor \& Francis Group. https://psycnet.apa.org/record/2008-09940-003

Saunders, M., Lewis, P., \& Thornhill, A. (2009). Research Methods for Business Students, (5th ed.). Harlow: Pearson Education.

Schippers, M. C., Den Hartog, D. N., Koopman, P. L., \& Wienk, J. A. (2003). Diversity and team outcomes: The moderating effects of outcome interdependence and group longevity and the mediating effect of reflexivity. Journal of Organizational Behavior: The International Journal of Industrial, Occupational and Organizational Psychology and Behavior, 24(6), 779802. https://doi.org/10.1002/job.220

Senior, B. (1997). Team roles and team performance: is there 'really'a link? Journal of occupational and organizational psychology, 70(3), 241-258. https://doi.org/10.1111/j.20448325.1997.tb00646.x

Shuffler, M., Kramer, W., Carter, D., Thayer, A., \& Rosen, M. (2018). Leveraging a teamcentric approach to diagnosing multiteam system functioning: the role of intrateam state profiles. Human Resource Management Review, 28(4), 361-361. https://doi:10.1016/j.hrmr.2017.08.003.

Sitkin, S. B., \& Pablo, A. L. (1992). Reconceptualizing the Determinants of Risk Behavior. Academy of Management Review, 17(1). https://doi.org/10.5465/amr.1992.4279564

Sitkin, S. B., \& Roth, N. L. (1993). Explaining the limited effectiveness of legalistic "remedies" for trust/distrust. Organization science, 4(3), 367-392. https://doi.org/10.1287/orsc.4.3.367

Smith, J. B., \& Barclay, D. W. (1997). The effects of organizational differences and trust on the Effectiveness of Selling Partner Relationships. Journal of Marketing, 61(1), 3-21. https://doi.org/10.1177/002224299706100102

Smith, K. G., Smith, K. A., Olian, J. D., Sims, H., H. P., O’Bannon, D. P., \& Scully, J. A. (1994). Top management team demography and process: The role of social integration and 
Rajapaksha B.P., Nishanthi H.M., KJM, 2021, 10 (02)

communication. Administrative Science Quarterly, 39(3), 412-438. http://dx.doi.org/10.2307/2393297

Status of sri lankan nr based industry. (n.d.). Retrieved from www.srilankabusiness.com: https://www.srilankabusiness.com/blog/status-of-sri-lankan-nr-based-

industry.html\#: :text=Both\%20new\%20pneumatic\%20tyres\%20and,to\%20Sri\%20Lanka's

$\% 20$ export\%20value.

Su, T. S., Chen, C., Cui, X., Yang, C., \& Ma, W. (2020). Consistency at different levels: A meta-analytic examination of organizational trust and performance. Nankai Business Review International, 11(4), 537-567. https://doi.org/10.1108/NBRI-01-2020-0005

Tajfel, H., \& Turner, J. C. (1979). The social psychology of intergroup relations. (W. G. Austin , \& S. Worchel , Eds.) Monterey, CA: Brooks/Cole.

Thommes, K. \& Klabuhn, J. (2019). Age and tenure diversity on the work floor: Evidence from a natural field experiment in production, Evidence-based HRM: A Global Forum for Empirical Scholarship, 9(1), 95-117,Emerald Group Publishing. https://ideas.repec.org/a/eme/ebhpps/ebhrm-04-2019-0033.html

Turner, J. C. (1982). Towards a cognitive redefinition of the social group. In H. Tajfel (Ed.), Social identity and intergroup relations (pp. 15-40). Cambridge, UK: Cambridge University Press.

West, M. (2001). The human team: basic motivations and innovations. In N. AndersonD. S. Ones, \& H. K. Sinangil Handbook of industrial, work \& organizational psychology - volume 2: Organizational psychology (270-288). SAGE Publications Ltd, https://www.doi.org/10.4135/9781848608368.n15

Wilkens, R., \& London, M. (2006). Relationships between climate, process, and performance in continuous quality improvement groups. Journal of Vocational Behavior, 69, 510-523. http://dx.doi.org/10.1016/j.jvb.2006.05.005

Zand, D. E. (1972). Trust and Managerial Problem Solving. Administrative Science Quarterly, 17(2), 229-239. https://doi.org/ 10.2307/2393957

Zhang, Z., Waldman, D. A., \& Wang, Z. (2012). A multilevel investigation of LeaderMember Exchange, informal leader emergence, and individual and team performance. Personnel Psychology, 65, 49-78. https://doi.org/10.1111/j.1744-6570.2011.01238.x 


\section{Appendices}

\section{Appendix A}

Table 1: Performance Statistics of X Tyres

\begin{tabular}{|c|c|c|c|c|c|c|c|}
\hline Period & $\begin{array}{c}\text { Prodcution } \\
\text { MT }\end{array}$ & G. Sales & $\begin{array}{c}\text { Profit from } \\
\text { Operations }\end{array}$ & PAT & $\begin{array}{c}\text { Cost of } \\
\text { Sales }\end{array}$ & $\begin{array}{c}\text { Export } \\
\text { Earnings }\end{array}$ & Cape x \\
\hline $2015(15 / 16)$ & 15,211 & $10,080,957$ & $2,026,787$ & $1,610,072$ & $5,689,022$ & $2,398,209$ & 764,304 \\
\hline $2016(16 / 17)$ & 15,200 & $10,327,260$ & $1,664,692$ & $1,289,355$ & $6,072,683$ & $1,473,528$ & 649,338 \\
\hline $2017(17 / 18)$ & 17,122 & $11,629,546$ & $1,291,693$ & $1,111,658$ & $7,248,667$ & $2,049,307$ & 298,922 \\
\hline $2018(18 / 19)$ & 16,074 & $12,056,055$ & $1,182,273$ & 989,247 & $7,603,842$ & $2,252,940$ & $1,234,200$ \\
\hline $\mathbf{2 0 1 9}(\mathbf{1 9 / 2 0}$ & $\mathbf{1 4 , 6 8 0}$ & $\mathbf{1 1 , 4 1 6 , 8 3 3}$ & $\mathbf{1 , 1 0 3 , 5 9 6}$ & $\mathbf{9 3 3 , 7 9 9}$ & $\mathbf{7 , 0 7 8 , 0 2 2}$ & $\mathbf{1 , 3 2 4 , 0 5 7}$ & $\mathbf{3 9 0 , 5 3 3}$ \\
\hline
\end{tabular}

Source: Annual Report 2019-2020 X Tyres 


\section{Appendix B}

Table 2: Results of KMO and Bartlett's Test on Team Trust and Team Performance

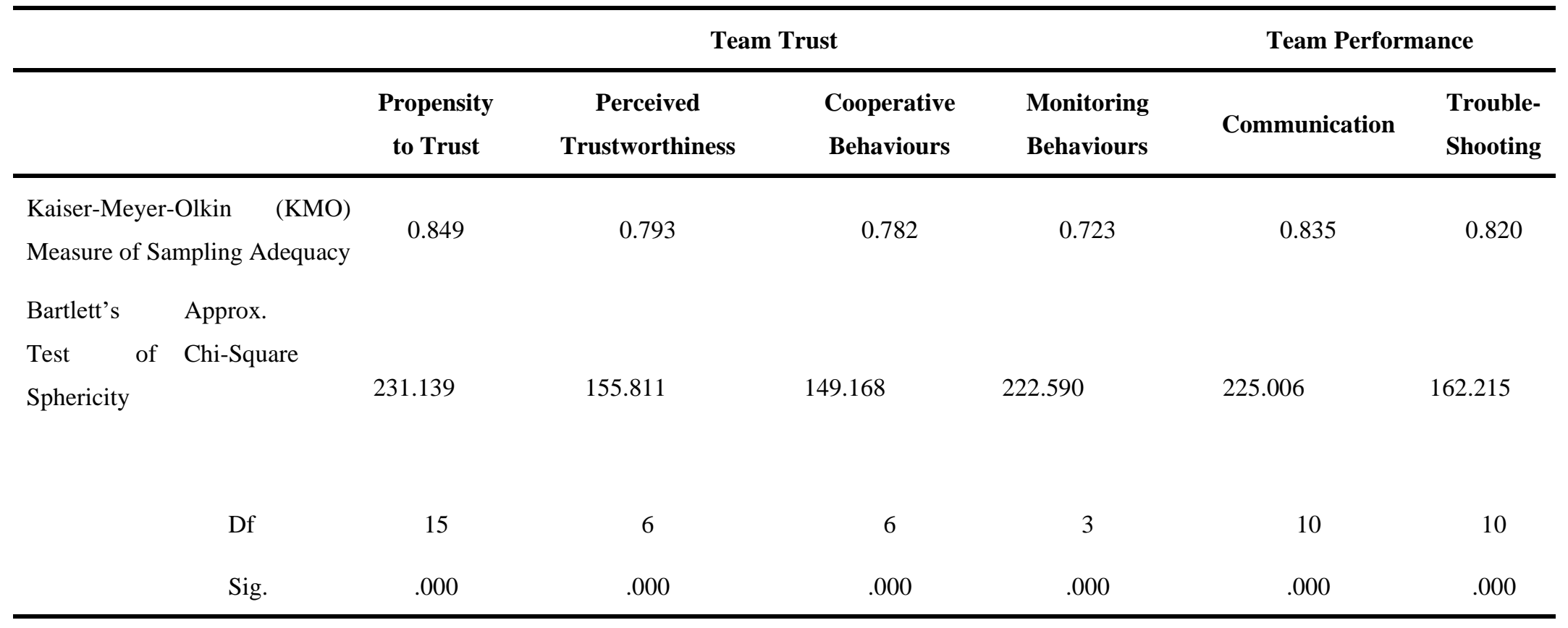

Source: Analysed data, 2021 


\section{Appendix C}

Table 3: Validity Statistics [Exploratory Factor Analysis (EFA)]

\begin{tabular}{llllll}
\hline Construct & Dimension/s & No. of Items & Lowest FT & Highest FT & ESSL Cum \% \\
\hline Team Trust & Propensity to Trust & 06 & 0.571 & 0.809 & 53.438 \\
& Perceived Trustworthiness & 04 & 0.763 & 0.850 & 63.800 \\
& Cooperative Behaviours & 04 & 0.724 & 0.827 & 0.930 \\
& Monitoring Behaviours & 03 & 0.867 & 0.859 & 62.422 \\
Team Performance & Communication & 05 & 0.722 & 0.574 \\
& Trouble Shooting & 05 & 0.667 & 0.798 & 54.904 \\
\hline
\end{tabular}

Source: Analysed data, 2021 


\section{Appendix D}

Table 4: Reliability Statistics

\begin{tabular}{llll}
\hline Construct/s & Dimension/s & No. of Items & Cronbach's Alpha \\
\hline Team Trust & Propensity to Trust & 06 & 0.821 \\
$($ Cronbach's Alpha $=0.831)$ & Perceived Trustworthiness & 04 & 0.810 \\
& Cooperative Behaviours & 04 & 0.797 \\
Team Performance & Monitoring Behaviours & 03 & 0.889 \\
$($ Cronbach's Alpha $=0.892)$ & Communication & 05 & 0.837 \\
\hline
\end{tabular}

Source: Analysed data, 2021 


\section{Appendix E}

Table 5: Descriptive Statistics of the Team Trust and Team Performance

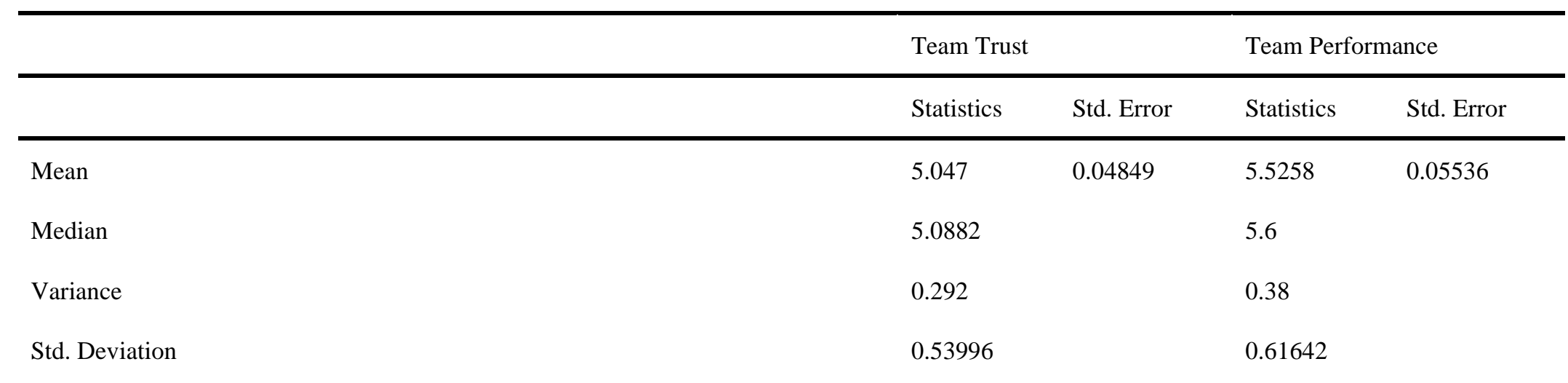

Source: Analysed data, 2021 


\section{Appendix F}

Table 6: Correlation Analysis

\begin{tabular}{|c|c|c|c|}
\hline \multirow{3}{*}{ Team Performance } & Pearson Correlation & 1 & $.721^{* *}$ \\
\hline & Sig. (2-tailed) & & .000 \\
\hline & $\mathrm{N}$ & 124 & 124 \\
\hline \multirow[t]{2}{*}{ Team Trust } & Sig. (2-tailed) & .000 & \\
\hline & $\mathrm{N}$ & 124 & 124 \\
\hline
\end{tabular}

**. Correlation is significant at the 0.01 level (2-tailed).

Source: Analysed data, 2021 


\section{Appendix G}

Table 7: Model Summary of Team Trust and Team Performance

Model

\begin{tabular}{llll}
\hline 1 & $.721^{\mathrm{a}} .521$ & .517 & .42857 \\
\hline a. Predictors: (Constant), Team Trust & \\
b. Dependent Variable: Team Performance \\
Source: Analysed data, 2021
\end{tabular}

R R Square Adjusted R Square Std. Error of the Estimate

\section{Appendix H}

Table 8: ANOVA Table of Team Trust and Team Performance

\begin{tabular}{lllllll}
\hline Model & & Sum of Squares & Df & Mean Square & F & Sig. \\
\hline \multirow{2}{*}{1} & Regression & 24.329 & 1 & 24.329 & 132.462 \\
& Residual & 22.408 & 122 & .184 & \\
& Total & 46.737 & 123 & & \\
\hline
\end{tabular}

a. Dependent Variable: Team Performance

b. Predictors: (Constant), Team Trust

Source: Analysed data, 2021

(c) (i)

Kelaniya Journal of Management | 2021 | Vol. 10 | Issue 02 | Page 144 


\section{Appendix I}

Table 9: Coefficients

\begin{tabular}{|c|c|c|c|c|c|c|}
\hline \multirow[t]{2}{*}{ Model } & & \multicolumn{2}{|c|}{ Unstandardized Coefficients } & \multicolumn{2}{|c|}{ Standardized Coefficients $t$} & \multirow[t]{2}{*}{ Sig. } \\
\hline & & B & Std. Error & Beta & & \\
\hline \multirow{2}{*}{1} & (Constant) & 1.369 & .363 & & 3.768 & .000 \\
\hline & Team Trust & .824 & .072 & .721 & 11.509 & .000 \\
\hline
\end{tabular}

a. Dependent Variable: Team Performance

Source: Analysed data, 2021

\section{Appendix J}

Table 10: ANOVA Table of Team Tenure and Team Trust

Team Trust

\begin{tabular}{|c|c|c|c|c|c|}
\hline & Sum of Squares & Df & Mean Square & $\mathbf{F}$ & Sig. \\
\hline Between Groups & 2.080 & 4 & .520 & 1.832 & .127 \\
\hline Within Groups & 33.782 & 119 & .284 & & \\
\hline Total & 35.861 & 123 & & & \\
\hline
\end{tabular}

Source: Analysed data, 2021 


\section{Appendix K}

Table 11: ANOVA Table of Team Tenure and Team Performance

Team Performance

\begin{tabular}{llllll}
\hline & Sum of Squares & Df & Mean Square & F & Sig. \\
\hline Between Groups & .515 & 4 & .129 & .331 & .857 \\
Within Groups & 46.223 & 119 & .388 & \\
Total & 46.737 & 123 & & \\
\hline
\end{tabular}

Source: Analysed data, 2021

\section{Appendix L}

Table 12: Model Summary

\begin{tabular}{|c|c|c|c|c|c|c|}
\hline $\mathbf{R}$ & R-sq & MSE & $\mathbf{F}$ & df1 & df2 & $\mathbf{p}$ \\
\hline .7308 & .5340 & .1815 & 45.8416 & 3.0000 & 120.0000 & .0000 \\
\hline \multicolumn{7}{|l|}{ Model } \\
\hline & coeff & Se & $\mathbf{T}$ & $\mathbf{p}$ & LLCI & ULCI \\
\hline constant & 1.8300 & .7909 & 2.3138 & .0224 & .2640 & 3.3960 \\
\hline Team Trust & .7018 & .1587 & 4.4234 & .0000 & .3877 & 1.0160 \\
\hline Team Tenure & -.2308 & .3048 & -.7573 & .4504 & -.8343 & .3727 \\
\hline Int_1 & .0589 & .0621 & .9485 & .3448 & -.0641 & .1820 \\
\hline
\end{tabular}

Product terms key:

Int_1 : TT $x$ Tепu

Source: Analysed data, 2021 